\title{
PARTY SYSTEM CHANGE IN A NEW DEMOCRACY: THE CASE OF MEXICO
}

\begin{abstract}
Since the end of the last century Mexico has experienced a profound process of political and electoral change which was reflected in its transition from a dominant party authoritarian regime to a competitive multiparty system. This paper has two parts and a concluding section. The first part focuses on major changes in a number of relevant dimensions of the Mexican party system, including electoral competitiveness, party fractionalisation, electoral volatility, nationalisation, and the aggregate distribution of partisan loyalties among the electorate (macropartisanship) over the last three decades. The analysis is based on aggregate electoral data at the national and the district level, as well as on data from surveys of public opinion. The paper shows important changes in the structure and behaviour of the Mexican electorate, such as increasing partisan de-alignment as well as growing competitiveness, fractionalisation, and nationalisation of the party system. The second part is a brief review of the factors driving the process of political and electoral change in Mexico.
\end{abstract}

\section{Key words}

Party system change, competitiveness, dealignment, volatility, fractionalisation, nationalisation

\section{Introduction}

Scholars of Mexican politics tend to agree that Mexican transition to democracy differed significantly from the elite-pact model of transitions described in the early action-focused democratisation literature (e.g. O’Donnell \& Schmitter, 1986; Przeworski, 1991). Perhaps the main difference in the Mexican transition

* Oniel Francisco Díaz Jiménez, Department of Social Processes, Division of Social Sciences and Humanities, Universidad Autonóma Metropolitana - Lerma, Mexico, o.diaz@correo.ler.uam.mx. 